\title{
Analisis Hubungan Produktivitas Dengan Technology Content PadaUsaha Kecil \& Menengah (UKM)
}

\author{
Mudji Astuti ${ }^{1}$, Hana Catur $\mathrm{W}^{2}$, Wiwik Sulistiyowati ${ }^{3}$, Udisubakti $\mathrm{C}^{4}$, Putu Dana $\mathrm{K}^{5}$ \\ ${ }^{1}$ Prodi Manajemen Universitas Muhammadiyah Sidoarjo \\ ${ }^{2,3}$ Prodi Teknik Industri Universitas Muhammadiyah Sidoarjo \\ ${ }^{4,5}$ Prodi Teknik Industri, ITS- Surabaya
}

\begin{abstract}
ABSTRAK
Usaha kecil dan menengah (UKM) merupakan sektor ekonomi penting di Indonesia, sehingga harus dijaga pertumbuhan dan perkembangannya. Penelitian ini bertujuan untuk mengehatui hubungan antara produktivitas dengan technology content, yang terdiri dari technoware (perangkat keras), humanware (sumber daya manusia), infoware (dokumen/ fakta, perangkat informasi), orgaware (kelembagaan/ peraturan). Jumlah sampel yang digunakan sebanyak 135 sampel UKM di wilayah kab Sidoarjo. Alat analisis yang digunakan adalah stuctural equation modelling (SEM). Hasil penelitian menunjukkan bahwa dari 9 hipotesis yang dirumuskan terdapat 2 hipotesis yang diterima, yaitu: technology content berhubungan positif dengan sumber daya manusia (H3) dan technology content berhubungan positif dengan kepemimpinan (H9).
\end{abstract}

Kata kunci : technology content, technoware, humanware, infoware, orgaware

\section{PENDAHULUAN}

Usaha Kecil dan Menengah (UKM) adalah sektor perekonomian yang sangat penting di Indonesia. Estimasi pertumbuhan pelaku usaha tersebut mencerminkan bahwa setiap pertumbuhan 1\% PDB akan menciptakan 42.797 pelaku usaha baru di Indonesia. Selain kontribusinya terhadap ekonomi Indonesia, UKM dipandang sebagai sektor yang handal dalam menghadapi terpaan krisis ekonomi. Hal ini terbukti ketika terjadi krisis ekonomi beberapa tahun lalu, UKM masih tetap eksis sementara usaha besar banyak yang gulung tikar (Indonesian Economic \& Small Medium Enterprises Outlook 2011). Selain itu, UKM merupakan penopang pertumbuhan ekonomi nasional dan berdampak langsung pada pertumbuhan ekonomi negara maju/ berkembang [1]. Dengan peningkatan produktivitas UKM, maka pertumbuhan UKM dapat ditingkatkan sehingga jumlah pengangguran di Indonesia dapat dikurangi menjadi 5\% pada tahun 2012.

Tetapi, dari sisi pemanfaatan teknologi, UKM di Indonesia hanya berkisar pada teknologi informasi (TI). Tingkat pemanfaatan teknologi informasi oleh UKM di Indonesia rendah, padahal pemanfaatan teknologi informasi di UKM dapat meningkatkan tranformasi bisnis melalui kecepatan, ketepatan dan efisiensi pertukaran informasi dalam jumlah yang besar dan dapat meningkatkan produktivitas UKM serta studi kasus di Eropa menunjukkan bahwa lebih dari 50\% produktifitas dicapai melalui investasi di bidang TI [2].

Padahal, pemanfaatan teknologi dapat dilakukan berdasarkan empat komponen, yaitu: technoware (perangkat keras), humanware (sumber daya manusia), infoware (dokumen/ fakta, perangkat informasi), orgaware (kelembagaan/ peraturan). Keempat komponen tersebut disebut dengan istilah technology content [3]. Oleh karena itu, penelitian ini dilakukan untuk mengetahui sejauh mana hubungan antara produktivitas dengan tecnology content pada UKM.

\section{LANDASAN TEORI}

\section{A. KAJIAN PUSTAKA}

Penelitian pendahuluan yang terkait dengan penelitian ini telah dilakukan oleh beberapa peneliti, antara lain [4] dalam penelitiannya tentang peran sumber daya dalam peran teknologi terhadap peningkatan produktivitas menunjukkan bahwa ketersediaan sumberdaya berperan penting dalam meningkatkan peran hard dan soft technology untuk meningkatkan produktivitas keseluruhan. Definisi kandungan teknologi menjadi empat 
komponen, yaitu: technoware meliputi peralatan, perlengkapan, mesin, alat pengangkutan dan infrastruktur fisik, humanware meliputi pengetahuan, ketrampilan, kebijakan, kreativitas, dan pengalaman, infoware berkaitan dengan proses prosedur, teknik, metode, teori, spesifikasi, pengamatan dan keterkaitan, orgaware mencakup praktek - praktek manajemen, keterkaitan dan pengaturan organisasi [3].

Dalam perkembangannya, teknologi harus didukung dengan inovasi agar selalu dapat memenuhi kebutuhan masyarakat, sehingga diperlukan suatu evaluasi terhadap tingkat inovasi teknologi yang digunakan oleh suatu perusahaan. Kemampuan inovasi teknologi (technological innovation capability) merupakan integrasi dari semua sumber daya yang ada di perusahaan [5]. Kemampuan inovasi teknologi dievaluasi berdasarkaan lima indikator yaitu: kemampuan penelitian dan pengembangan (R\&D), kemampuan inovasi dalam membuat keputusan, kemampuan dalam pemasaran, kemampuan produksi, kemampuan modal. Agar pemanfaatan teknologi dapat dilakukan secara optimal, maka perlu adanya pengelolaan terhadap sumber daya manusia sebagai operator teknologi. Untuk itu, diperlukan suatu strategi dalam pengelolaan sumber daya manusia (SDM), karena hal ini sangat berpengaruh pada semua komponen bisnis dalam perusahaan. Penelitian tentang pengelolaan SDM untuk meningkatkan kinerja bisnis dari perspektif pemegang saham menunjukkan bahwa operasional perusahaan menjadi lebih efektif dan realistik [6].

Penelitian adanya hubungan antara kompetensi sumberdaya manusia dengan kinerja UKM menunjukkan bahwa kompetensi SDM yang terdiri dari pengetahuan (knowledge), ketrampilan (skill) dan kemampuan (ability) mempunyai pengaruh yang signifikan pada kinerja UKM, kecuali kemampuan tidak mempunyai pengaruh yang signifikan pada kinerja UKM [7]. Penelitian tentang pengaruh ukuran tim dan teknologi informasi pada produktivitas kerja menunjukkan bahwa ukuran tim dan teknologi informasi mempunyai pengaruh yang signifikan pada produktivitas kerja [8].

Penyelarasan strategi bisnis dengan teknologi informasi akan memberikan pengaruh positif pada produktivitas perusahaan, sehingga diperlukan pendefinisian strategi bisnis ke tujuan bisnis dalam teknologi informasi Untuk melakukan hal tersebut maka memerlukan suatu kerangka kerja baku sehingga mampu memberikan peluang besar terhadap efisiensi dan efektifitas penerapan teknologi informasi. Hal tersebut dapat dilakukan dengan menerapkan kerangka kerja COBIT (Control Objectives for Information and Related Technology). COBIT mendefinisikan tujuan bisnis terkait dengan aktivitas teknologi informasi pada umumnya yang ada diperusahaan. Sumber daya teknologi informasi merupakan suatu elemen yang sangat disoroti COBIT, termasuk pemenuhan kebutuhan bisnis terhadap efektivitas, efisiensi, kerahasiaan, keterpaduan, ketersediaan, kepatuhan terhadap kebijakan dan kehandalan teknologi informasi [9].

Persaingan bisnis yang semakin dinamis dan berkembang sangat memerlukan sistem manajemen yang efektif dan efisien sehingga organisasi tidak lagi dipandang sebagai suatu sistem tertutup tetapi organisasi sebagai suatu sistem terbuka yang harus dapat merespon dan mengakomodasi perubahan eksternal dengan cepat dan efisien. Salah satu nilai terpenting dalam perusahaan adalah kepemimpinan (leadership). Kepemimpinan merupakan suatu proses dimana seseorang dapat menjadi pemimpin melalui aktivitas yang terus menerus sehingga dapat mempengaruhi yang dipimpinnya dalam rangka mencapai tujuan organisasi atau perusahaan [10]. Banyak faktor yang mempengaruhi kepemimpinan sehingga kepemimpinan seseorang dapat berdampak positif bagi produktivitas perusahaan. Penelitian tentang faktor - faktor yang mempengaruhi kepemimpinan menunjukkan bahwa 5 faktor terbesar yang berpengaruh pada kepemimpinan adalah: pembawa perubahan, komunikasi, kepemimpinan dalam pekerjaan, jejaring, pengembang orang lain [11]. Peningkatan produktivitas merupakan tujuan utama perusahaan sebagai perubahan efektivitas dan efisiensi dari sumber daya menjadi suatu produk yang dapat dipasarkan dan memberikan keuntungan. Oleh karena itu, indikator dan faktor diarahkan untuk meningkatkan produktivitas. Salah satu faktor penting untuk meningkatkan produktivitas 
adalah pelaksanaan program Keselamatan dan Kesehatan kerja (K3) di perusahaan. Pelaksanaan K3 diharapkan dapat menurunkan tingkat kecelakaan kerja dan penyakit akibat kerja sehingga dapat meningkatkan produktivitas kerja [12]. Perkembangan produktivitas dari periode ke periode dapat diukur berdasarkan indek total produktivitas dengan beberapa kriteria,yaitu: produktivitas tenaga kerja, produktivitas bahan baku, produktivitas modal, dan produktivitas energi [13].

\section{B. TEKNOLOGI}

Memasuki era global, perubahan teknologi semakin cepat dan kompleks. Hal ini membuat teknologi menjadi faktor kritis dalam lingkungan persaingan global. Teknologi menjadi bagian dari aspek persaingan bisnis, bahkan teknologi telah menginvasi semua kehidupan bisnis . Bidang bisnis seperti keuangan, pemasaran dan perekayasaan akan menggunakan teknologi sebagai basis persaingan (based competition). Selain itu teknologi merupakan suatu strategi dalam menghadapi perkembangan yang terus berlangsung di dunia.

Teknologi terintegrasi dalam suatu proses bisnis, sehingga banyak definisi tentang teknologi disesuaikan dengan profesi tertentu. Seorang ilmuwan fisika mendefinisikan teknologi sebagai suatu alat yang digunakan oleh sorang ahli untuk mengadakan eksperimen, proses teknologi adalah manifestasi dari keempat elemen dan interaksi antara komponen-komponennya, yaitu technoware, humanware, infoware dan orgaware [3]. Teknologi adalah cara atau metode serta proses atau produk yang dihasilkan dari penerapan dan pemanfaatan berbagai disiplin ilmu pengetahuan yang menghasilkan nilai bagi pemenuhan kebutuhan, kelangsungan dan peningkatan mutu kehidupan manusia [14].

Technoware $(\mathrm{T})$ : object- embedded technology $=$ physical facilities $=$ perangkat teknis, peralatan produksi: fasilitas berwujud fisik mencakup peralatan, perlengkapan, mesin - mesin, kendaraan bermotor, pabrik, infrastruktur fisik dan barang - barang modal lainnya yang digunakan manusia dalam mengoperasikan suatu transformasi produk. Technoware menunjang tenaga manusia dan proses kontrol transformasi operasi. Dalam suatu kegiatan bisnis, technoware mengalami perubahan periodik antara yang tua dan yang baru. Secara umum, tingkat kemajuan (sophistication) dari technoware berkaitan dengan tingkat kompleksitas (dalam hal ini termasuk skala produksi, hubungan sesame proses, cakupan output, tipe konversi, kebutuhan energi, kualitas output, keamanan lingkungan untuk operasi dsb) dari fasilitas fisik untuk transformasi operasi dan fungsi fungsi lainnya.

Humanware $(\mathrm{H})$ : person embedded technoloyr: human abilities: berwujud kemampuan sumber daya manusia yang meliputi pengetahuan, ketrampilan/ keahlian, kebijakan, kreativitas, prestasi dan pengalaman seseorang atau sekelompok orang dalam memanfaatkan sumber daya alam dan teknologi yang tersedia. Humanware berubah melalui proses pembelajaran dari hal - hal yang baru. Biasanya, tingkat kemajuan humanware mengindikasikan peningkatan keompetensi individu. Kompetensi adalah suatu tingkat keahlian, training yang tepat, peningkatan pengalaman orientasi produktivitas, potensi kreativitas dan motivasi personil. Humanware yang mengalami tingkat kemajuan (degree of sophistication) adalah kemampuan menggunakan teknologi yang berkaitan dengan pekerjaannya, kemampuan untuk memobilisasi, mempersiapkan dan menggunakan komponen teknologi untuk pekerjaan, kemampuan untuk mengoptimalkan kerja dari seluruh komponen dan kemampuan untuk menjalankan komponen inovasi untuk meningkatkan kesejahteraan.

Infoware (I): document embedded technology: document fact: berwujud dokumen fakta, perangkat informasi, yang berkaitan dengan proses, prosedur, teknik, metode, teori spesifikasi, desain, observasi, manual dan fakta linnya yang diungkapkan melalui publikasi, dokumen dan cetak biru. Infoware berubah melalui proses komulatif dari akuisisi pengetahuan. Infoware dapat mempercepat pembelajaran dan penghematan waktu serta sumber daya. Secara sederhana, peningkatan infoware mencerminkan tingkat utilitas 
dari pengetahuan terkini yang dapat dimanfaatkan dalam berbagai usaha. Utilitas itu sendiri tergantung dari sifat dan tipe ilmu pengetahuan (relevansi, batasan waktu, ketersediaan data dan fakta), kemampuan mencerna pengetahuan yang tersimpan dan pengembangan jaringan untuk pembaharuan.

Orgaware (O): institution embedded technology: organizational framework: berwujud kerangka kerja organisasi, perangkat organisasi/ kelembagaan dan peraturan, dibutuhkan untuk mewadahi perangkat teknis, kemampuan sumber daya manusia, dan perangkat informasi, terdiri dari praktek - praktek manajemen, keterkaitan dan pengaturan organisasi untuk mencapai hasil yang positif. Orgaware biasanya digunakan untuk koordinasi aktifitas dan penggunaan sumber daya untuk mencapai sesuatu yang diinginkan. Komponen orgaware berubah melalui proses praktek dan keterlibatan dalam manajemen. Tingkat kemajuan orgaware menunjukkan peningkatan nilai tambah, kemajuan penggunaan teknik manajemen baru, metode dan keterkaitannya dengan persaingan pasar serta rasa percaya diri dalam perusahaan.

Setiap bisnis harus mampu mengkombinasikan keempat komponen dari teknologi tersebut. Kompleksitas interaksi dari komponen - komponen tersebut dapat menghasilkan output yang mengandung teknologi dengan berbagai kombinasi. Untuk menghadapi persaingan pasar yang global, seluruh bisnis memiliki target degree of sophistication yang paling tinggi. Namun demikian, secara simultan keempat komponen teknologi tersebut harus diperbarui secara simultan agar dapat berkompetisi dipasar. Setiap komponen teknologi akan memberikan kontribusi yang berbeda pada pertumbuhan dan tingkat competitiveness suatu siklus hidup perusahaan.

\section{PRODUKTIVITAS}

Terdapat berbagai macam pengertian produktivitas. The Organization for European Economic Cooperation (OEEC, 1950) menyebutkan bahwa produktivitas merupakan hasil bagi antara output dengan keseluruhan atau salah satu faktor produksi yang digunakan, antara lain modal, investasi yang dikeluarkan dan bahan baku yang digunakan [15].

Definisi produktivitas sebagai perbandingan ukuran harga bagi masukan dan hasil, juga merupakan perbedaan antara kumpulan jumlah pengeluaran dan masukkan yang dinyatakan dalam satuan - satuan (unit) umum [16]. Untuk dapat mengetahui tingkat produktivitas pada level tertentu, maka perlu dilakukan pengukuran produktivitas. Pengukuran produktivitas merupakan suatu alat manajemen yang penting di semua tingkatan ekonomi. Pengukuran produktivitas pada level perusahaan memberikan beberapa keuntungan, antara lain: sebagai indikator ekonomi, sebagai manpower analiysis, yang merupakan alat untuk mengetahui sejauh mana tenaga kerja telah digunakan, sebagai company performance analysis, yaitu untuk membandingkan performance antar perusahaan, firm dan trade association forecast, yaitu meramalkan kondisi perdagangan dimasa yang akan datang.

Berbagai kajian tentang produktivitas menunjukkan bahwa peningkatan produktivitas berkorelasi dengan pertumbuhan ekonomi suatu Negara [17]. Peningkatan produktivitas merupakan indikator terjadinya percepatan pertumbuhan investasi indusri, efisiensi produksi, dan merupakan sumber terjadinya pertumbuhan Gross Development Product (GDP) [18]. Peningkatan produktivitas dipengaruhi oleh pengelolaan manajemen, bahan baku, biaya, teknologi dan sistem kepemimpinan yang kurang baik, sehingga tidak mampu mencapai tujuan yang telah ditetapkan. Rendahnya kualitas sistem kepemimpinan terlihat dari tingginya angka turnover dan absensi karyawan [19]. Dalam hubungannya dengan teknologi, produktivitas dan teknologi merupakan entitas yang berbeda, tetapi saling berhubungan, terutama dalam pemanfaatan teknologi informasi sehingga investasi untuk penerapan teknologi baru dalam suatu perusahaan akan mempengaruhi peningkatan produktivitas [20]. 
Peningkatan produktivitas sebagai tujuan utama perusahaan dapat terjadi jika ada potensi peningkatan produktivitas dan potensi tersebut diterapkan. Artinya, potensi peningkatan produktivitas tidak akan terjadi jika tidak dilaksanakan. Potensi adalah pengetahuan, sumber daya, integrasi, manajemen, inovasi, keahlian, kesadaran dan persaingan. Proses merupakan suatu penerapan potensi, semakin sering menerapkan potensi, produktivitas akan semakin tinggi [21].

\author{
Potensi: \\ 1.Pengetahuan \\ 2.Sumberdaya \\ 3. Integrasi \\ 4. Manajemen \\ 5.Inovasi \\ 6.Keahlian \\ 7.Kesadaran \\ 8.Persaingan
}

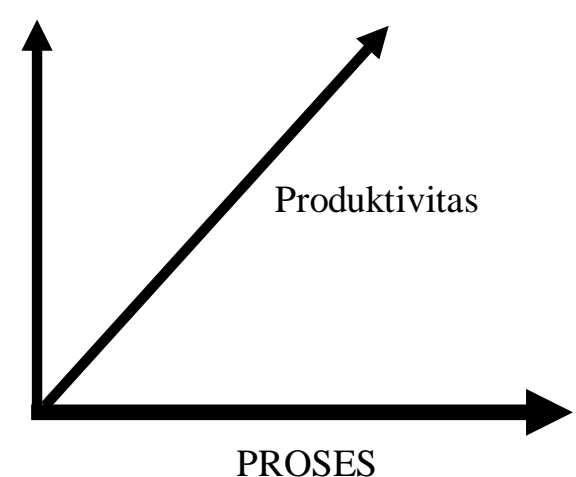

Gambar 1. Peningkatan produktivitas Sumber: Singgih, 2010

Penelitian tentang faktor yang mempengaruhi produktivitas dari tinjauan keselamatan, kesehatan dan lingkungan kerja menunjukkan bahwa keselamatan dan kesehatan kerja berpengaruh secara langsung pada produktivitas kerja. Hasil penelitian tersebut juga memperlihatkan bahwa lingkungan kerja dari sisi fisik berpengaruh pada pada kesehatan, namun tidak berpengaruh pada keselamatan kerja tetapi berpengaruh secara tidak langsung terhadap produktivitas melalui keselamatan kerja. Lingkungan kerja dari sisi psikologi dan sosial berpengaruh langsung terhadap keselamatan kerja namun tidak berpengaruh terhadap kesehatan kerja dan berpengaruh tidak langsung terhadap produktivitas melalui kesehatan kerja [22].

Secara ekonomi, produktivitas sering diukur berdasarkan rasio antara output yang dihasilkan dengan input yang digunakan. Penelitian tentang produktivitas total mengungkapkan bahwa konsep tentang produktivitas total dapat digunakan untuk mengukur tingkat produktivitas di level bisnis (perusahaan). Total produktivitas diukur berdasarkan rasio output dengan indikator input yang berbentuk profit, modal, energi dan bahan baku. Penelitian ini menunjukkan bahwa pengukuran produktivitas berdasarkan indikator profit, modal, energi dan bahan baku dapat memberikan gambaran tentang perkembangan kondisi produktivitas perusahaan yang sebenarnya [13].

\section{USAHA KECIL DAN MENENGAH (UKM)}

Usaha Kecil dan Menengah (UKM) merupakan unsur utama pembangunan ekonomi bangsa yang saat ini menjadi prioritas untuk dikembangkan. Hal ini dikarenakan UKM merupakan sistem ekonomi kerakyatan yang mampu mengurangi masalah kesenjangan antar golongan pendapatan dan antar pelaku usaha, pengentasan kemiskinan dan penyerapan tenaga kerja. Lebih dari itu, pengembangan UKM mampu memperluas basis ekonomi dan dapat memberikan konstribusi yang signifikan dalam mempercepat perubahan struktural, yaitu meningkatnya perekonomian daerah dan ketahanan ekonomi 
nasional dan sejalan dengan fakta yang menunjukkan bahwa UKM memiliki kemampuan untuk menciptakan lapangan kerja dengan biaya minimum, pelopor dalam dunia inovasi dan memiliki fleksibilitas tinggi yang memungkinkan usaha tersbut untuk memenuhi kebutuhan pelanggan [1].

Usaha kecil dan menengah (UKM) didefinisikan oleh Badan Pusat Statistik (BPS) sebagai perusahaan dengan jumlah tenaga kerja antara 5 sampai 19 karyawan ( BPS, 1997). Perusahaan dengan kurang dari 5 karyawan disebut home industry. UKM didefinisikan sebagai industri kecil sebagai perusahaan dengan jumlah karyawan antara 5 sampai dengan 49 karyawan. Pengertian industri kecil/UKM juga dapat dipandang dari jumlah produksi atau hasil penjualan dan dari sisi nilai tambah [23].

\section{METODOLOGI PENELITIAN}

Teknik analisis yang digunakan untuk pendekatan kuantitatif adalah dengan metode Structural Equation Modeling (SEM), karena SEM mampu menggambarkan suatu hubungan informasi sebab akibat antar data statistik dan memberikan penilaian secara kuantitatif hubungan antara variabel - variabel yang diteliti [24,25]. Obyek penelitian yang digunakan adalah UKM manufaktur di wilayah Kabupaten Sidoarjo, karena tersedianya banyak UKM di Sidoarjo yang mencapai 169.673 UKM sampai akhir 2011 (Data Dinas Perindustrian UKM Sidoarjo, 2012). Sedangkan Pengumpulan data dilakukan dengan menggunakan beberapa metode, yaitu:

a. Kuisioner

Kuisioner digunakan untuk mengetahui pengaruh technology content pada peningkatan produktivitas UKM. Penilaian responden menggunakan skala Likert yang banyak digunakan untuk mengukur sikap, pendapat, dan persepsi [26]. Responden diminta untuk mengindikasikan tingkat persetujuan atau ketidaksetujuan terhadap masing-masing pertanyaan. Pada penelitian ini penilaian yang digunakan dengan menggunakan 5 kategori skor respon penilaian yang terwakili oleh skor 1 (sangat tidak setuju), skor 2 (tidak setuju), skor 3 (cukup setuju), skor 4 (setuju), dan skor 5 (sangat setuju).

b. In Depth Interview

In depth interview dilakukan dengan cara wawancara terstruktur dan wawancara tak terstruktur terhadap key informant yang telah ditetapkan sebelumnya. Wawancara dilakukan kepada pihak-pihak yang mengerti tentang UKM, Misalnya pada kepala/ manajer produksi yang mengetahui dengan baik bagaimana kondisi sebenarnya di UKM, bagaimana produk yang dihasilkan, fungsi teknologi bagi UKM dll. In depth interview dilakukan untuk mengerti dan mengetahui kondisi existing UKM.

c. Dokumentasi

Dokumentasi pada penelitian ini digunakan untuk mengumpulkan data - data yang terkait dengan penelitian, berasal dari data primer atau data sekunder.

d. Observasi

Observasi pada penelitian ini digunakan untuk mengamati secara langsung kondisi dan kegiatan yang ada di UKM. Misalnya, kegiatan proses produksi yang berkaitan dengan teknologi yang digunakan dalam proses produksi, kemampuan sumberdaya manusia, sistem informasi yang digunakan dan sistem pengelolaan keorganisasian yang berkaitan dengan produktivitas UKM. Observasi ini dilakukan untuk melengkapi data hasil in depth interview.

e. Focus Group Discussion (FGD)

FGD merupakan teknik pengumpulan data yang dilakukan untuk menemukan makna sebuah tema menurut pemahaman suatu kelompok [28]. FGD pada penelitian ini digunakan untuk mengetahui secara lebih dalam tentang pengelolaan dan pengembangan tehcnology content untuk meningkatkan produktivitas UKM. FGD dilakukan melalui sebuah forum yang dihadiri oleh berbagai pihak terkait misalnya dari kalangan pelaku UKM, akademisi, dan pemerintahan. 


\section{Indikator Penelitian}

Variabel laten yang terbentuk dalam kerangka teoritis penelitian masih belum dapat dikatakan sebagai variabel yang terukur sehingga membutuhkan variabel indikator sebagai dasar model pengukurannya. Tabel 1 . berikut ini menunjukkan variabel dan indikator penelitian yang menjadi bahan menyusun question research penelitian.

Tabel 1. Indikator Penelitian

\begin{tabular}{|c|c|c|}
\hline \multirow{5}{*}{$\begin{array}{c}\text { Variabel laten } \\
\text { Technology content (P1) }\end{array}$} & \multicolumn{2}{|r|}{ Indikator } \\
\hline & P1.1 & Techoware \\
\hline & P1.2 & Humanware \\
\hline & P1.3 & infoware \\
\hline & P4.4 & Orgaware. \\
\hline \multirow{5}{*}{$\begin{array}{l}\text { Kemampuan inovasi teknologi } \\
\text { (P2) }\end{array}$} & P2.1 & Penelitian dan pengembangan \\
\hline & P2.2. & Inovasi dalam membuat keputusan \\
\hline & P2.3. & Pemasaran \\
\hline & P2.4 & Produksi \\
\hline & P2.5 & Modal \\
\hline \multirow[t]{3}{*}{ Sumber daya manusia (P3) } & P3.1 & Knowladge \\
\hline & P3.2 & Ability \\
\hline & P3.3 & Skill \\
\hline \multirow[t]{6}{*}{ Teknologi informasi (P4) } & P4.1 & Efektifitas \\
\hline & P4.2 & Efisiensi \\
\hline & P4. 3 & Kerahasian \\
\hline & P4. 4 & Integritas \\
\hline & P4.5 & Kepatuhan \\
\hline & P7.6 & Keakuratan informasi \\
\hline \multirow[t]{5}{*}{ Kepemimpinan (P5) } & P5.1 & Pembawa perubahan \\
\hline & P5.2 & Komunikasi \\
\hline & P5.3 & Kepemimpinan dalam pekerjaan \\
\hline & P5.4 & Jejaring \\
\hline & P5.5 & Pengembang bagi orang lain \\
\hline \multirow[t]{4}{*}{ Peningkatan produktivitas (P6) } & P6.1 & Modal \\
\hline & P6.2 & Tenaga kerja \\
\hline & P6.3 & Energi \\
\hline & P6.4 & Bahan baku \\
\hline
\end{tabular}

Perumusan hipotesis pada penelitian ini didasarkan pada hasil review teoritis dan empiris yang terdiri dari:

Tabel 2. Hipotesis penelitian

\begin{tabular}{|l|l|l|l|}
\hline Hipotesis 1 & $:$ & $\begin{array}{l}\text { Terdapat hubungan positif antara techonology content dengan } \\
\text { produktivitas }\end{array}$ \\
\hline Hipotesis 2 & $:$ & $\begin{array}{l}\text { Terdapat hubungan positif antara techonology content dengan kemampuan } \\
\text { inovasi teknologi }\end{array}$ \\
\hline Hipotesis 3 & $:$ & $\begin{array}{l}\text { Terdapat hubungan positif antara techonology content dengan sumber daya } \\
\text { manusia }\end{array}$ \\
\hline Hipotesis 4 & $:$ & $\begin{array}{l}\text { Terdapat hubungan positif antara techonology content dengan teknologi } \\
\text { informasi }\end{array}$ \\
\hline Hipotesis 5 & $:$ & $\begin{array}{l}\text { Terdapat hubungan positif antara techonology content dengan } \\
\text { kepemimpinan }\end{array}$ \\
\hline Hipotesis 6 & $:$ & Terdapat hubungan positif antara kemampuan inovasi produk dengan \\
\hline
\end{tabular}




\begin{tabular}{|l|l|llll|}
\hline & & produktivitas & & & \\
\hline Hipotesis 7 & $:$ & $\begin{array}{l}\text { Terdapat hubungan positif antara sumber daya manusia dengan } \\
\text { produktivitas }\end{array}$ & $\begin{array}{l}\text { Terdapat hubungan positif antara teknologi informasi dengan } \\
\text { produktivitas }\end{array}$ & Hipotesis 8 & Terdapat hubungan positif antara kepemimpinan dengan produktivitas \\
\hline Hipotesis 9 & $:$ & &
\end{tabular}

\section{HASIL DAN PEMBAHASAN}

Jumlah Sampel Penelitian

Jumlah sampel yang digunakan sebanyak 135 sampel UKM di wilayah Kab. Sidoarjo

\section{Indentitas Responden}

a. Identitas Responden Berdasarkan Lokasi Penelitian

\section{Lokasi Pengambilan Data UKM}

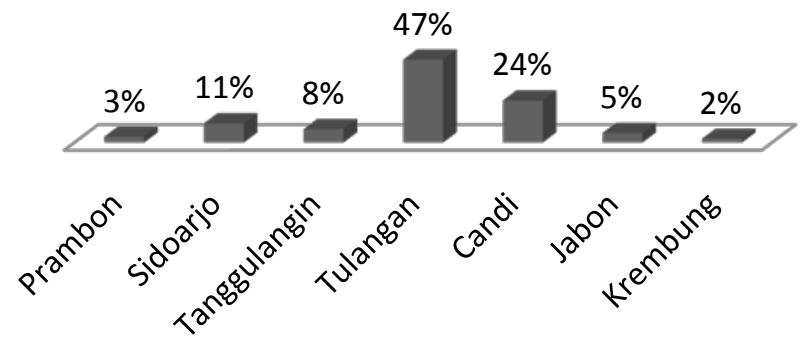

Gambar 1. Indentitas responden berdasarkan lokasi penelitian

b. Indentitas responden berdasarkan tingkat pendidikan

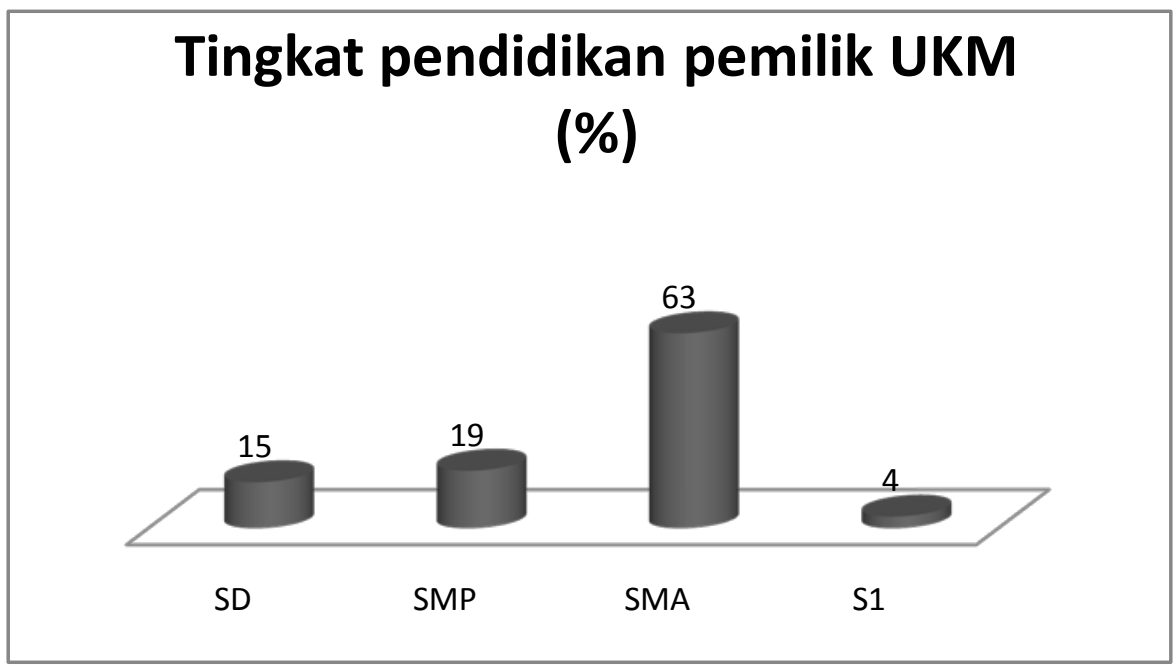

Gambar 2. Identitas responden berdasarkan pendidikan 
c. Indentitas responden berdasarkan lama menjalankan usaha

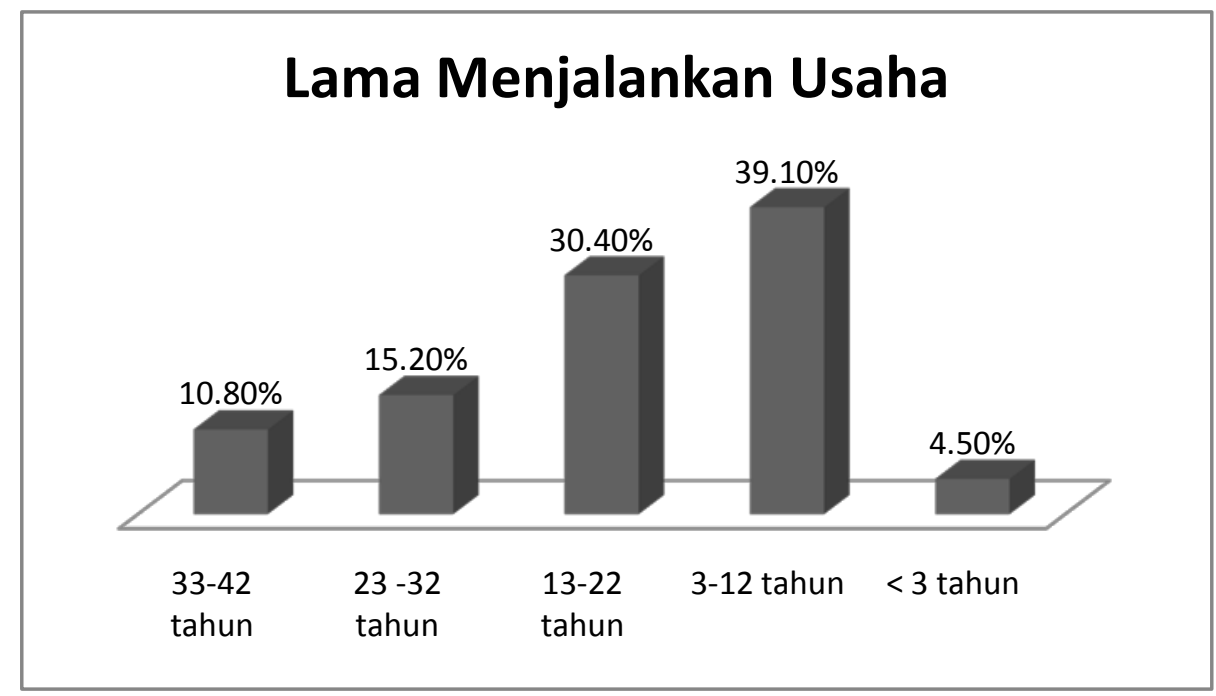

Gambar 3. Indentitas responden berdasarkan lama menjalankan usaha

\section{Hasil Uji Validitas Dan Reliabilitas}

Uji reliabilitas ini digunakan untuk melihat sejauh mana suatu hasil pengukuran itu relatif konsisten. Dinyatakan reliable jika nilai alpha cronbach lebih besar dari 0,5. Uji reliabilitas dilakukan dengan menggunakan SPSS 16 dan hasilnya menunjukkan sebagai berikut:

Tabel 3. Hasil SPSS untuk uji reliabilitas

Reliability Statistics

\begin{tabular}{|r|r|r|}
\hline $\begin{array}{c}\text { Cronbach's } \\
\text { Alpha }\end{array}$ & $\begin{array}{c}\text { Cronbach's } \\
\text { Alpha Based } \\
\text { on } \\
\text { Standardized } \\
\text { Items }\end{array}$ & \\
\hline .982 & .984 & N of Items \\
\hline
\end{tabular}

Berdasarkan tabel 3. diketahui bahwa nilai alpha cronbach sebesar 0,984. Nilai tersebut lebih besar dari 0,5, sehingga dapat disimpulkan bahwa data hasil kuisioner adalah reliabel.

Sedangkan uji validitas digunakan untuk mengetahui apakah kuisioner yang digunakan benar benar dapat digunakan untuk mengetahui apa yang ingin di ukur. Taraf signifikansi yang digunakan adalah $5 \%$. Uji validitas dilakukan dengan menggunakan SPSS 16 dan hasilnya sebagai berikut:

Tabel 4. Hasil uji validitas dengan SPSS 16.

\begin{tabular}{|l|l|l|c|c|c|}
\hline Variabel laten & \multicolumn{2}{|c|}{ Indikator } & R Tabel & R Hitung & Keterangan \\
\hline \multirow{3}{*}{$\begin{array}{l}\text { Technology } \\
\text { content (P1) }\end{array}$} & P1.1 & Techoware & 0,1416 & 0,807 & Valid \\
\cline { 2 - 6 } & P1.2 & Humanware & 0,1416 & 0,771 & Valid \\
\cline { 2 - 6 } & P1.3 & Infoware & 0,1416 & 0,929 & Valid \\
\cline { 2 - 6 } & P4.4 & Orgaware. & 0,1416 & 0,930 & Valid \\
\hline $\begin{array}{l}\text { Kemampuan } \\
\text { inovasi teknologi } \\
(\mathrm{P} 2)\end{array}$ & $\mathrm{P} 2.1$ & $\begin{array}{l}\text { Penelitian dan } \\
\text { pengembangan }\end{array}$ & 0,1416 & 0,902 & Valid \\
\cline { 2 - 6 } & $\mathrm{P} 2.2$. & Inovasi dalam & 0,1416 & 0,875 & Valid \\
\hline
\end{tabular}




\begin{tabular}{|c|c|c|c|c|c|}
\hline & & $\begin{array}{l}\text { membuat } \\
\text { keputusan }\end{array}$ & & & \\
\hline & P2.3. & Pemasaran & 0,1416 & 0,924 & Valid \\
\hline & P2.4 & Produksi & 0,1416 & 0,893 & Valid \\
\hline & P2.5 & Modal & 0,1416 & 0,804 & Valid \\
\hline \multirow{3}{*}{$\begin{array}{l}\text { Sumber daya } \\
\text { manusia (P3) }\end{array}$} & P3.1 & Knowladge & 0,1416 & 0,931 & Valid \\
\hline & P3.2 & Ability & 0,1416 & 0,876 & Valid \\
\hline & P3.3 & Skill & 0,1416 & 0,504 & Valid \\
\hline \multirow{6}{*}{$\begin{array}{l}\text { Teknologi } \\
\text { informasi (P4) }\end{array}$} & P4.1 & Efektifitas & 0,1416 & 0,876 & Valid \\
\hline & P4.2 & Efisiensi & 0,1416 & 0,871 & Valid \\
\hline & P4. 3 & Kerahasian & 0,1416 & 0,884 & Valid \\
\hline & P4. 4 & Integritas & 0,1416 & 0,909 & Valid \\
\hline & P4.5 & Kepatuhan & 0,1416 & 0,900 & Valid \\
\hline & P7.6 & $\begin{array}{l}\text { Keakuratan } \\
\text { informasi }\end{array}$ & 0,1416 & 0,910 & Valid \\
\hline \multirow[t]{5}{*}{$\begin{array}{l}\text { Kepemimpinan } \\
\text { (P5) }\end{array}$} & P5.1 & $\begin{array}{l}\text { Pembawa } \\
\text { perubahan }\end{array}$ & 0,1416 & 0,876 & Valid \\
\hline & P5.2 & Komunikasi & 0,1416 & 0,850 & Valid \\
\hline & P5.3 & $\begin{array}{l}\text { Kepemimpinan } \\
\text { dalam pekerjaan }\end{array}$ & 0,1416 & 0,878 & Valid \\
\hline & P5.4 & Jejaring & 0,1416 & 0,873 & Valid \\
\hline & P5.5 & $\begin{array}{l}\text { Pengembang bagi } \\
\text { orang lain }\end{array}$ & 0,1416 & 0,914 & Valid \\
\hline \multirow{4}{*}{$\begin{array}{l}\text { Peningkatan } \\
\text { produktivitas } \\
\text { (P6) }\end{array}$} & P6.1 & Modal & 0,1416 & 0,659 & Valid \\
\hline & P6.2 & Tenaga kerja & 0,1416 & 0,805 & Valid \\
\hline & P6.3 & Energi & 0,1416 & 0,872 & Valid \\
\hline & P6.4 & Bahan baku & 0,1416 & 0,705 & valid \\
\hline
\end{tabular}

Sumber: pengolahan data

Berdasarkan tabel 4 diketahui bahwa nilai $\mathrm{R}$ hitung $>\mathrm{R}$ tabel. Hasil tersebut menunjukkan bahwa semua indikator yang digunakan dalam penelitian adalah valid.

\section{Pengujian Hipotesis}

Pengujian hipotesis dilakukan untuk menguji pengaruh antar variabel penelitian sesuai dengan hipotesis yang telah dirumuskan sebelumnya. Selain itu, pengujian ini dilakukan untuk melihat sifat hubungan (positif atau negatif) antar variabel penelitian. Hubungan positif berarti peningkatan pada salah satu variabel akan mengakibatkan meningkatnya variabel yang lain. Sedangkan, hubungan negatif terjadi jika peningkatan variabel yang satu akan mengakibatkan menurunnya variabel yang lainnya.

Pengujian hipotesis berdasarkan nilai $\mathrm{t}$ value di masing- masing variabel yang diperoleh dalam pengolahan data menggunakan software AMOS. Ketentuan yang digunakan adalah jika t value $>0,5$ (50\%) maka hubungan antar variabel tersebut adalah signifikan. Berdasarkan hipotesis yang telah ditentukan dan pengolahan data yang telah dilaksanakan maka hasilnya terlihat pada tabel 5 berikut ini:

Tabel 5. Hasil pengujian hipotesis

\begin{tabular}{|l|l|l|l|l|}
\hline Hipotesis & \multicolumn{1}{|c|}{ Hubungan } & Nilai t value & Signifikansi & Keterangan \\
\hline Hipotesis & $\begin{array}{l}\text { Terdapatrabungan } \\
\text { positif } 0,08 \\
\text { techonology antara } \\
\text { dengan produktivitas }\end{array}$ & & Tidak signifikan & H1 ditolak \\
\hline
\end{tabular}




\begin{tabular}{|c|c|c|c|c|}
\hline $\begin{array}{l}\text { Hipotesis } \\
2\end{array}$ & $\begin{array}{lr}\text { Terdapat } & \text { hubungan } \\
\text { positif } & \text { antara } \\
\text { techonology content } \\
\text { dengan kemampuan } \\
\text { inovasi teknologi }\end{array}$ & 0,15 & Tidak signifikan & H2 ditolak \\
\hline $\begin{array}{l}\text { Hipotesis } \\
3\end{array}$ & $\begin{array}{l}\text { Terdapat hubungan } \\
\text { positif antara } \\
\text { techonology content } \\
\text { dengan sumber daya } \\
\text { manusia }\end{array}$ & 0,63 & Signifikan & H3 diterima \\
\hline $\begin{array}{l}\text { Hipotesis } \\
4\end{array}$ & $\begin{array}{lr}\text { Terdapat } & \text { hubungan } \\
\text { positif } & \text { antara } \\
\text { techonology } & \text { content } \\
\text { dengan r } & \text { teknologi } \\
\text { informasi } & \end{array}$ & 0,04 & Tidak signifikan & H4 ditolak \\
\hline $\begin{array}{l}\text { Hipotesis } \\
5\end{array}$ & $\begin{array}{lr}\text { Terdapat } & \text { hubungan } \\
\text { positif } & \text { antara } \\
\text { techonology } & \text { content } \\
\text { dengan } & \\
\text { kepemimpinan }\end{array}$ & 0,35 & Tidak signifikan & H5 ditolak \\
\hline $\begin{array}{l}\text { Hipotesis } \\
6\end{array}$ & $\begin{array}{lr}\text { Terdapat } & \text { hubungan } \\
\text { positif } & \text { antara } \\
\text { kemampuan } & \text { inovasi } \\
\text { produk } & \text { dengan } \\
\text { produktivitas } & \end{array}$ & 0,27 & Tidak signifikan & H6 ditolak \\
\hline $\begin{array}{l}\text { Hipotesis } \\
7\end{array}$ & $\begin{array}{l}\text { Terdapat hubungan } \\
\text { positif antara sumber } \\
\text { daya manusia dengan } \\
\text { produktivitas }\end{array}$ & 0,01 & Tidak signifikan & H7 ditolak \\
\hline $\begin{array}{l}\text { Hipotesis } \\
8\end{array}$ & $\begin{array}{lr}\text { Terdapat } & \text { hubungan } \\
\text { positif } & \text { antara } \\
\text { teknologi informasi } \\
\text { dengan produktivitas }\end{array}$ & $-0,23$ & Tidak signifikan & H8 ditolak \\
\hline $\begin{array}{l}\text { Hipotesis } \\
9\end{array}$ & $\begin{array}{l}\text { Terdapat hubungan } \\
\text { positif antara } \\
\text { kepemimpinan } \\
\text { dengan produktivitas }\end{array}$ & 0,62 & Signifikan & H9 diterima \\
\hline
\end{tabular}

Sumber : Hasil pengolahan data

\section{PEMBAHASAN}

Berdasarkan hasil pengujian hipotesis terlihat bahwa terdapat 2 hipotesis yang diterima, yaitu: hipotesis 3 (terdapat hubungan positif antara techonology content dengan sumber daya manusia) dan hipotesis 9 (terdapat hubungan positif antara kepemimpinan dengan produktivitas). Hasil ini menegaskan bahwa faktor sumber daya manusia (SDM) dan kepemimpinan penting untuk peningkatan produktivitas UKM. Faktor SDM terkait dengan keahlian dan kemampuan dalam menjalankan proses produksi. Sedangkan faktor kepemimpinan menjadi penting bagi peningkatan produktivitas UKM terkait dengan peran pemimpin dalam memberikan motivasi, cara bersikap ketika menghadapi permasalahan dan menegur para karyawan. Hal ini dikarenakan, UKM belum mempunyai peraturan- peraturan baku dalam pengelolaan karyawan (sumber daya manusia), sehingga faktor kebijakan pimpinan memberi peran penting. Dan sebagian besar, pemimpin dalam UKM adalah pemilik 
usaha. Sikap pemimpin dapat menjadi faktor penghambat atau pendorong terjadinya turn over karyawan.

\section{KESIMPULAN DAN SARAN KESIMPULAN}

Kesimpulan yang dapat ditarik dari hasil penelitian adalah:

1. Tidak terdapat hubungan positif antara technologi content dengan peningkatan produktivitas UKM.

2. Tidak terdapat hubungan positif antara technology content dengan kemampuan inovasi teknologi UKM.

3. Terdapat hubungan positif antara technology content dengan sumber daya manusia UKM.

4. Tidak terdapat hubungan positif antara technology content dengan teknologi informasi UKM.

5. Tidak terdapat hubungan positif antara technology content dengan kepemimpinan UKM.

6. Tidak terdapat hubungan positif antara kemampuan inovasi produk dengan produktivitas UKM.

7. Tidak terdapat hubungan positif antara sumber daya manusia dengan produktivitas UKM.

8. Tidak terdapat hubungan positif antara teknologi informasi dengan produktivitas UKM.

9. Terdapat hubungan positif antara kepemimpinan dengan produktivitas UKM.

\section{SARAN}

Berdasarkan hasil penelitian maka diharapkan adanya peran Pemerintah dalam pembinaan UKM terutama terkait dengan peningkatan kemampuan SDM (Karyawan) dan pola kepemimpinan untuk pemilik usaha melalui berbagai macam pelatihan.

\section{DAFTAR PUSTAKA}

[1] Munizu, 2010, Pengaruh faktor - faktor eksternal dan internal terhadap kinerja usaha mikro dan kecil di Sulawesi Selatan, Jurnal Manajemen dan Kewirausahaan Vol 12 No 1, Maret, 33- 41.

[2] Wahid, Iswari, 2007, Adopsi Teknologi Informasi Oleh Usaha Kecil Dan Menengah Di Indonesia, Seminar Aplikasi Teknologi Informasi, Yogyakarta, 16 Juni.

[3] Smith, Sharif,2007, Understanding And Acquiring Technology Assets For Global Competition, Technovation 27, pp 643-649

[4] Ellitan, 2003, Peran Sumber Daya DalamMeningkatkan Pengaruh Teknologi Terhadap Produktivitas, Jurnal Manajemen \& Kewirausahaan, Vol 5 No 2, September, 155-170.

[5] Wang, Yuan Lu, Chen, 2008, Evaluating firm technological innovation capability under uncertainty, Technovation 28, pp 349- 363.

[6] Xirogiannis Chytas, Glykas, Valiris, 2007, Intelligent Impact Assesment Of HRM To Shareholder Value, Expert System With Applications xxx, xxx-xxx

[7] Ardiana, Brahmayanti, Subaedi, 2010, Kompetensi SDM UKM dan Pengaruhnya Terhadap Kinerja UKM di Surabaya, Jurnal Manajemen dan Kewirausahaan, Vol 12, No 1, Maret, 42-55.

[8] Oktarini, Subagyo, Pardadi, 2008, Analisa Pengaruh Ukuran Tim dan Teknologi Informasi Terhadap Produktivitas Tim Kerja Pada Lini Quality Control, Seminar Nasional Aplikasi Sains dan Teknologi, IST Akprin Yogyakarta.

[9] Anggraini, 2009, Audit Implementasi Biometrics Fingerprints (Studi kasus Sistem Absensi STIMIK Yogyakarta), Seminar Nasional Aplikasi Teknologi Informasi, Juni, Yogyakarta.

[10] Brahmasari, Suprayetno, 2008, Pengaruh Motivasi Kerja, Kepemimpinan dan Budaya Organisasi Terhadap Kepuasan Kerja Karyawan, Serta Dampaknya Pada Kinerja 
Perusahaan, Jurnal Manajemen dan Kewirausahaan, Vol 10 No 2, Sepetember, 124135.

[11] Woworuntu, 2003, Determinan Kepemimpinan, Makara, Sosial Humaniora, Vol 7 No 2, Desember, hal 71-80.

[12] Muklishani, Wigyosubroto, Sudarso, 2008, Pendekatan Metode Semi Equation Modeling Untuk Analisa Faktor Yang Mempengaruhi Produktivitas Dari Tinjauan Keselamatan, Kesehatan dan lingkungan Kerja Di PT Barata Indonesia (Persero) Gresik, Proseding Seminar Nasional Manajemen Teknologi, MMT, ITS.

[13] Hannula, 2002, Total Productivity Measirement Based on Partial Productivity Ratio, International Journal Of Production Economics, 78, 57-67.

[14] Khalil, 2000, Manajement Of Technology: The Key to Competitiveness and Wealth Creation, McGraw Hill, New York.

[15] Desheng, Chien Ta Bruce Ho, 2007, Productivity and efficiency analysis of taiwan integrated circuit industry, International journal of productivity and performance management, vol 56 no 8, pp 715-730.

[16] Sinungan, 2005, Produktivitas,Apa dan Bagaimana Produktivitas, PT Bumi Akasara.

[17] Fernandez, 2008, Firm Productivity In Bangladesh Manufacturinf Industries, World Development, Vol 36 No 10 pp 1725-1744.

[18] Al Salman, 2008, Measuring The Technological Change And Productivity in Food, Textile And Chemical Industries In Kuwait (1992-2002), Telematic and Informatic 25, 237-245.

[19] Lily M.T.,Obiajulu E.U.,Ogaji S.O.T.,Probert S.D., 2007, Total Productivity Analysis Of A Nigerian Petroleum Product Marketing Company, Applied Energy 84, 1150- 1173

[20] Palazuelos, Fernandez, 2008, Demanad, Employment, Labor Productivity In The European Economies, Structural Change and Economic Dynamic, doi:10.1016

[21] Singgih, M.L, 2010, Peningkatan produktivitas Melalui Perbaikan Proses Untuk Meningkatkan Daya Saing, Pidato Pengukuhan Untuk Jabatan Guru Besar Dalam Bidang Ilmu Analisis Produktivitas Pada Jurusan Teknik Industri Fakultas Teknologi Industri, ITS, Surabaya.

[22] Mukhlisani, Wigyosubroto, Sudarso, 2008, Pendekatan Metode Semi Equation Modeling Untuk Analisa Faktor Yang Mempengaruhi Produktivitas Dari Tinjauan Keselamatan, Kesehatan dan lingkungan Kerja Di PT Barata Indonesia (Persero) Gresik, Proseding Seminar Nasional Manajemen Teknologi, MMT, ITS.

[23] Hill, H, 1990, Indonesia's Industrial Tranformation Part I, Bulletin Of Indonesian Economic Studies, Vol 26, No 2 August, pp $79-120$

[24] Narimawati U., Sarwono J, 2007, Structural Equation Modeling (SEM) dalam Riset Ekonomi Menggunakan Lisrel, Gava Media, Yogyakarta.

[25] Ulegin, Kabak, Onsel, Ulegin \& Aktas E, 2010, A Problem Structural Model For Analyzing Transportation - Enviorement Relationship, European Journal of Operational Risearch, Vol 200, pp 844- 859.

[26] Ghozali I, Fuad, 2008, Structural Equation Modeling: Teori, Konsep dan Aplikasi Dengan Program LISREL 8.80, Semarang, Badan Penerbit Universitas Diponegoro.

[27] Ariyani W,D.,2002, Manajemen Kualitas, Penedekatan sisi kualitatif, Ghalia Indonesia, Jakarta. 